\title{
Paulina Olechowska, Akcesja Polski do Unii Europejskiej na tamach prasy regionalnej Ziem Zachodnich, Wydawnictwo Naukowe Uniwer- sytetu Szczecińskiego, Szczecin 2012, ss. 284.
}

Tematyka związana $\mathrm{z}$ akcesją Polski do Unii Europejskiej doczekała się bardzo wielu publikacji autorstwa badaczy reprezentujących często odmienne dyscypliny naukowe. Fakt ten odzwierciedla wielowymiarowość zagadnienia, które stało się również przedmiotem recenzowanej rozprawy. Autorka w mnogości publikacji podkreślających ekonomiczne, prawno-międzynarodowe, polityczne oraz społeczne konsekwencje akcesji Polski do Unii Europejskiej odnalazła, cały czas, niewystarczająco omówione pole badawcze, skupiające, niczym w soczewce, wyżej wymienione aspekty. Recenzowana publikacja składa się z sześciu rozdziałów, wstępu, zakończenia, bibliografii oraz streszczenia. Niepodważalnym atutem książki jest bogate wykorzystanie rozmaitych załączników: map, tabel oraz wykresów, które zostały zebrane w ostatniej części monografii.

W omawianej pracy wyróżnić można dwie części. Pierwsza, służąca czytelnikowi jako wprowadzenie do podjętej problematyki, koncentruje się na pierwszych dwóch rozdziałach. Pozostałe cztery rozdziały stanowią natomiast wyniki przeprowadzonych przez Autorkę badań. Autorka już we $W$ stępie zaznacza, iż „bez zaangażowania mediów trudno byłoby obywatelom państw należących do Unii Europejskiej wprowadzić w życie podstawowe reformy". Szczególna rola w tym procesie przypadła codziennej prasie ogólnoinformacyjnej. W dalszej części Wstepu Autorka przedstawia zakres geograficzny, chronologiczny oraz merytoryczny pracy. Po zapoznaniu czytelnika z przyjętymi kryteriami i przedmiotem badań przedstawiona i omówiona została literatura przedmiotu, co stanowi cenną wskazówkę dla badaczy podejmujących w swych rozważaniach podobną tematykę oraz podkreśla bardzo dobrą znajomość omawianego zagadnienia.

W rozdziale pierwszym omówiona została rola strategii informacyjnej w kwestii akcesji Polski do Unii Europejskiej. W długiej drodze Polski do Unii Europejskiej, szczególne miejsce przypadło Narodowej Strategii Integracji. Dokument ten został wypracowany jako rezultat negocjacji środowisk naukowych, organizacji pozarządowych oraz ministerstw i urzędów administracji centralnej. Został on przyjęty 28 stycznia 1997 roku i stanowił swoisty drogowskaz akcentujący konieczne dalsze przedsięwzięcia, które Polska winna spełnić by dołączyć do rodziny państw Unii Europejskiej. Autorka zauważa, iż prowadzone od 1991 roku działania informacyjne miały jednak zasięg ograniczony, a swoisty przełom nastapił w $1997 \mathrm{roku}$, kiedy powołane zostało Centrum Informacji Europejskiej. W dalszej części rozdziału Autorka omawia główne cele rządowej kampanii informacyjnej, której istotnym elementem był Program Informowania Społeczeństwa. Paulina Olechowska zauważa, iż założenia programu odbiegały od sposobu jego realizacji. Niekonsekwencja ta wynikała jej zdaniem z braku wystarczającej koordynacji ze strony rządu oraz szerokiego ukierunkowania informacji do wszystkich środowisk, w tym również niezainteresowanych pogłębieniem swego stanu wiedzy, eurosceptyków oraz osób niezdecydowanych. W drugiej części rozdziału Autorka przedstawiła założenia i realizację kampanii przed- i poreferendalnej. Kampania przed-referendalna stanowiła istotną część w procesie przedstawiania Polakom rzetelnych informacji na temat szans wynikających z członkostwa i tym samym zmobilizowania ich do udziału w referendum. Przeprowadzona w dwóch odsłonach kampania, zdaniem Autorki, nie miała jednorodnego charakteru, ponieważ różne ośrodki decyzyjne prowadziły własne akcje. Odmienną strategię przyjęto po referendum europejskim, co przejawiało się określeniem trzech grup odbiorców i, jak zauważa Autorka, odmiennej formy przekazu uzależnionej od danego profilu grupy. Bardzo ważną zdaje się być kontestacja poczyniona przez P. Olechowską, iż omówiona kampania informacyjna była jednym z ważniejszych przedsięwzięć politycznych po 1989 roku, w którym porozumiały się różne partie. Stanowiło to jej zdaniem pierwszy sygnał o stopniowym zacieraniu się różnic ideowo-historycznych skut- 
kujących podziałem na postkomunę i postsolidarność, który jednak nadal obecny jest w szeroko rozumianym dyskursie politycznym.

Rozdział drugi koncentruje się na charakterystyce prasy regionalnej w polskim systemie medialnym oraz omawia metodologię badań podjętych przez Autorkę. Rozdział ten systematyzuje konieczną dla dalszej lektury wiedzę poprzez ukazanie rozmaitych definicji oraz typologii prasy regionalnej. Autorka przedstawia następnie charakterystykę dzienników regionalnych, które stały się dla niej materiałem źródłowym recenzowanej publikacji. W rozdziale omówiono także przemiany, które nastąpiły w Polsce po 1989 roku, a które wynikały z likwidacji Robotniczej Spółdzielni Wydawniczej „Prasa - Książka - Ruch”. W omawianej części rozprawy, Autorka zaprezentowała również pięć hipotez badawczych oraz szczegółowo przedstawiła klucz kategoryzacyjny.

Akcesja Polski do Unii Europejskiej w prasie regionalnej województwa zachodniopomorskiego stanowi temat trzeciego rozdziału publikacji. Autorka scharakteryzowała w nim aktywność ugrupowań politycznych, których posłowie ezęsto wypowiadali się na łamach prasy zachodniopomorskiej. Paulina Olechowska zauważa, iż pewien przełom w prowadzeniu polityki informacyjnej oraz jej percepcja pośród mediów nastapił w styczniu 2003, kiedy nastąpiła zmiana na stanowisku ministra do spraw informacji europejskiej. Autorka kontestuje dalej, iż o sukcesie prowadzonej kampanii zadecydowało także zaangażowanie się Prezydenta RP, Aleksandra Kwaśniewskiego wraz z małżonką. W dalszej części rozdziału Autorka prezentuje opinię lokalnych dziennikarzy i czytelników po przeprowadzonym 7 i 8 czerwca 2003 roku referendum europejskim. Stwierdza ona, iż okres poreferendalny cechował się niemal całkowitym zanikiem zagadnień unijnych $w$ analizowanej prasie. Coraz więcej tekstów traktowało o tematach lekkich, nie brakowało także tekstów publicystycznych i komentarzy. Istotne miejsce w rozdziale poświęcone zostało także stosunkom polsko-niemieckim, które stały się elementem dyskusji dotyczącej akcesji Polski do Unii Europejskiej. Autorka ukazała specyficzny charakter współpracy międzyregionalnej ze szczególnym uwzględnieniem współpracy transgranicznej. Wartym zaznaczenia jest stwierdzenie, iż Niemcy przedstawiane były w prasie zachodniopomorskiej jako zwolennik i adwokat interesów Polski w Unii Europejskiej. Głównymi autorami tekstów prasowych byli przedstawiciele władz samorządowych, kół gospodarczych i, co ważne, także mieszkańcy województwa. Oczywistym jest, iż po obu stronach pojawiały się wątpliwości oraz lęki, które Autorka również scharakteryzowała. Rozdział czwarty poświęcony został odzwierciedleniu drogi Polski do Unii Europejskiej na łamach dzienników regionalnych województwa lubuskiego. Publikowane materiały korespondowały $z$ kolejnymi ważnymi wydarzeniami, jak zamknięcie negocjacji akcesyjnych, podpisanie traktatu akcesyjnego czy przeprowadzenie referendum akcesyjnego. Każdy z nich został rzetelnie omówiony przez Autorkę publikacji a umieszczone wykresy i tabele znacznie ułatwiły lekturę pracy. Szczególne miejsce w tekstach zamieszczonych na łamach gazet lubuskich zajęła kwestia postrzegania Niemiec jako adwokata polskich starań o członkostwo w Unii Europejskiej. W dalszej części Autorka omawia historyczny rozwój porozumień Polaków z Niemcami. Przeprowadzając wnikliwą analizę, Autorka stwierdza, iż „,elem tekstów prasowych, poświęconych polsko-niemieckiej tematyce, było przedstawienie lubuskim czytelnikom korzyści płynących z pogłębiania sąsiedzkich stosunków z Niemcami". Interesującym zabiegiem w dalszej części rozdziału jest zestawienie przez Autorkę argumentów przeciwników i zwolenników wstąpienia Polski do Unii Europejskiej, wśród których znajdowali się przede wszystkim pracownicy sektora gospodarki czy lokalni politycy. Również politycy z tzw. ,pierwszych stron gazet” brali udział w licznych festynach promujących akcesję Polski do Unii.

Tematem piątego rozdziału Autorka uczyniła obraz starań Polski o członkostwo w Unii Europejskiej w dziennikach dolnośląskich. Pod wieloma względami struktura rozdziału przypomina model zastosowany w czwartym rozdziale. Autorka również omawia charakter relacji polsko-niemieckich oraz ukazuje opinie dolnośląskich Autorów na temat Unii Europejskiej, 
którzy na bieżąco krytykowali potknięcia rządu w działaniach promocyjnych. Autorka podkreśla, iż pewną cechą charakterystyczną tekstów dzienników dolnośląskich było częste zwracanie się o opinię do znanych polityków. Wydarzeniem najczęściej komentowanym było jednak referendum europejskie, zjawisko to Autorka opisuje szczegółowo w dalszej części rozdziału. Ocenie poddane zostały także opinie lokalnych liderów, zarówno reprezentujących środowisko naukowe, sferę polityki czy religii. Tocząca się kampania informacyjna stała się swoistym poligonem, na którym zderzały się racje zarówno entuzjastów, jak i przeciwników akcesji. Podobnie jak w poprzednim rozdziale istotne miejsce Autorka poświęciła kwestii stosunków polsko-niemieckich. W przeciwieństwie do tekstów zamieszczonych w prasie lubuskiej i zachodniopomorskiej, materiały prasowe dzienników dolnośląskich problematyce polsko-niemieckiej poświęciły najmniej miejsca.

Ostatni, szósty rozdział stanowi zebranie i podsumowanie badań przeprowadzonych przez Autorkę. Paulina Olechowska zestawiła trzynaście dzienników, które były przedmiotem jej badań celem przeprowadzenia analizy porównawczej. W rezultacie czytelnik otrzymał bardzo interesujący materiał, z którego wynika między innymi, iż najwięcej tekstów poświęconych Unii Europejskiej ukazało się w województwie Zachodniopomorskim oraz, iż podsycanie euroentuzjazmu przed referendum skutkowało wzrostem sceptycyzmu wobec przystapienia Polski do Unii. Analizie porównawczej poddane zostały także wypowiedzi liderów opinii publicznej, jak i materiały traktujące o wzajemnych relacjach Polski i Niemiec. Publikacja Pauliny Olechowskiej stanowi bardzo istotny wkład w studia nad problematyką akcesji Polski do Unii Europejskiej. Walorem pracy jest również jej przystępny język, dzięki któremu również czytelnik zaczynający swą intelektualną przygodę z tematyką integracji Polski z Unią Europejską nie poczuje się zawiedziony.

\section{RAFAŁ KAMPROWSKI}

\section{Marek Rewizorski, Beata Przybylska-Maszner, System Instytucjo- nalny Unii Europejskiej po traktacie z Lizbony. Aspekty polityczne i prawne, Wydawnictwo Difin, Warszawa 2012, ss. 482.}

Najnowsza książka badaczy legitymujących się już sporym dorobkiem piśmienniczym została poświęcona systemowi instytucjonalnemu UE po wejściu w życie Traktatu z Lizbony. Jest to interesujące, nowatorskie i oryginalne ujęcie tak ważnych zagadnien, dodatkowo nasycone dużym ładunkiem treści teoretycznych. Przyjęta optyka badawcza ustawia badaną problematykę pod nieco innym kątem, dotąd nieeksplorowanym naukowo, przez co książka zyskuje na atrakcyjności. Przyjęte hipotezy badawcze i cele założone w pracy pozwalają lepiej udzielić odpowiedzi chociażby na pytania o znaczenie przeobrażeń, które zaszły w strukturze instytucjonalnej UE, czy o instytucje mające największy wpływ na kreowanie polityki Unii ze względu na kompetencje prawodawcze oraz inicjatywę ustawodawczą.

Rozpoczynając poszukiwania badawcze, autorzy przeprowadzili szeroko zakrojoną kwerendę i zgromadzili wiele materiałów źródłowych, książek, artykułów, dokumentów unijnych zarówno w j. polskim, jak i obcym, stanowiących reprezentatywną literaturę dla podjętego przez autorów przedmiotu badań.

Książka jest obszerna, ale ze względu na precyzję słowa i zwięzłość wypowiedzi nie sprawia trudności w lekturze. Autorzy posiadają dobrze ugruntowaną wiedzę w zakresie opisywanych zagadnień, a ich opinie i komentarze są klarowne i spójne. 